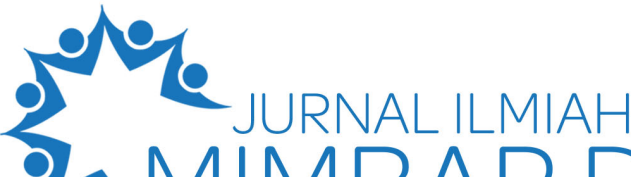 מMIMBAR DEMOKRASI

Vol. 21 No. 1 October 2021 | Hal. $19-28$

\section{Peran orang tua dalam pendidikan karakter peserta didik selama pembelajaran online}

\begin{abstract}
Amelia Haryanti a, 1*, Dindin ${ }^{\text {b, } 2}$
a Universitas Pamulang, Indonesia

1 dosen00811@unpam.ac.id*; 2dosen02573@unpam.ac.id;

*korespondensi penulis

Informasi artikel

Diterima:

18-08-2021

Disetujui:

12-09-2021

Kata kunci:

Peran orang tua

Pembelajaran online

Karakter

ABSTRAK

Tujuan dari dilaksanakannya penelitian ini adalah untuk mengetahui peran orang tua/wali peserta didik dalam membentu karakter peserta didik selama pembelajaran online di masa pandemi covid-19 serta kendala-kendala yang dihadapi oleh orang tua selama pembelajaran online. Metode yang digunakan dalam penelitian ini adalah pendekatan kualitatif dengan penelitian studi kasus. Subjek penelitian yang digunakan adalah orang tua/wali peserta didik di Kelurahan Pondok Benda Kecamatan Pamulang Kota Tangerang Selatan. Teknik pengumpulan data menggunakan observasi, dokumentasi, dan wawancara. Hasil penelitian yang didapatkan adalah sebagai berikut: Orang tua lebih berusaha dalam menumbuhkan nilai-nilai karakter peserta didik selama pembelajaran online, orang tua memberikan contoh nyata antara materi pelajaran dengan contoh nyata dalam kehidupan sehari-hari yang dapat disaksikan dan dirasakan langsung oleh peserta didik di lingkungan tempat tinggalnya, adapun kendala yang dihadapi oleh orang tua adalah cara penyampaian dalam memberikan pemahaman tentang materi pembelajaran kepada peserta didik, tidak sebaik guru di sekolah. untuk mengatasi permasalahan tersebut orang tua membuat grup dengan guru Pendidikan Kewarganegaraan untuk sama-sama melakukan pengawasan dan konsultasi berkaitan dengan materi pembelajaran agar peserta didik maksimal dalam memahami pembelajaran selama pembelajaran online.
\end{abstract}

\section{Received: \\ 18-08-2021 \\ Accepted: \\ 12-09-2021 \\ Keywords: \\ Role of parents \\ Online learning \\ Character}

\section{ABSTRACT}

The role of parents in character education of students during online learning. The purpose of this research is to find out the role of parents / guardians of learners in helping the character of learners during online learning in the covid-19 pandemic and the obstacles faced by parents during online learning. This research method uses a qualitative approach with case studies. The research subjects used were parents / guardians of learners in Pondok Benda Village, Pamulang District of South Tangerang City. Data collection techniques use observation, documentation, and interviews. The results of the research obtained are as follows: Parents are more trying to foster the character values of learners during online learning, parents provide real examples between subject matter and real examples in everyday life that can be witnessed and felt directly by learners in the environment where they live, while the obstacles faced by parents are the way of delivery in providing understanding of learning materials to learners, not as good as teachers in school. To overcome these problems parents create a group with Civic Education teachers to jointly conduct supervision and consultation related to learning materials so that learners are maximal in understanding learning during online learning.

Copyright (C) 2021 (Amelia Haryanti \& Dindin). All Right Reserved

How to Cite: Haryanti, A. \& Dindin (2021). Peran orang tua dalam pendidikan karakter peserta didik selama pembelajaran online. Jurnal Ilmiah Mimbar Demokrasi,21(1), 19-28. DOI: http://doi.org/10.21009/jimd.v21i1.22497

This work is licensed under a Creative Commons Attribution-ShareAlike 4.0 International License. Allows readers to read, download, copy, distribute, print, search, or link to the full texts of its articles and allow readers to use them for any other lawful purpose. The author (s) bolds the copyright.

\section{Pendahuluan}

Pandemi covid-19 masih saja terus berlangsung, belum ada tanda-tanda kapan akan mereda. Bahkan peningkatan kasus pasien yang terpapar semakin hari semakin meningkat. Hal ini membuat tenaga kesehatan dan pemerintah kewalahan menangani kasus pasien yang tidak kunjung menurun, pasien yang terindikasi covid memenuhi hampir seluruh rumah sakit dan fasilitas-fasilitas kesehatan di seluruh pulau Jawa, 
belum lagi semakin hari, jumlah kematian semakin meningkat, instalasi gawat darurat (IGD) over, sampai-sampai banyak pasien yang tidak tertangani di rumah sakit, belum lagi banyaknya jumlah kematian pasien covid ketika menjalani isolasi mandiri. Hal ini semakin membuat resah masyarakat dan pemerintah, betapa tidak, semakin hari jumlah pasien semakin banyak, sampai-sampai fasilitas kesehatan kewalahan menangani pasien covid, sehingga pasien lain yang bukan covid kesulitan untuk masuk perawatan IGD. Belum meredanya pandemi ini membuat pemerintah mengundurkan rencana pembelajaran secara tatap muka, yang tadinya akan dilaksanakan pada tahun ajaran 2021/2022 menjadi diundur kembali, entah sampai kapan. Belajar Dari Rumah (BDR) sesuai keputusan Menteri Pendidikan dan Kebudayaan Republik Indonesia terkait Surat Edaran Nomor 4 Tahun 2020 tentang Pelaksanaan Kebijakan Pendidikan dalam Masa Darurat Penyebaran Covid-19, dan Surat Edaran Mendikbud Nomor 36962/MPK.A/HK/2020 tentang pembelajaran secara daring dan bekerja dari rumah dalam rangka pencegahan penyebaran (covid-19). Dengan adanya kebijakan ini memaksa guru dan murid untuk tetap bekerja dan belajar dari rumah. Hal ini membuat orang tua peserta didik harus memperpanjang perannya kembali, selain menjadi ibu rumah tangga, karyawati/pekerja, sekaligus juga menjadi guru di rumah, mengawasi anak-anaknya belajar, berperan sebagai mentor. Peran orang tua yang muncul selama pandemi covid-19 adalah sebagai pembimbing, pendidik, penjaga, dan pengembang anak. Pandemi covid19 menuntut peran orang tua untuk aktif secara maksimal dalam pembelajaran anak. Peran orang tua dalam membantu anak belajar dari rumah di antaranya memastikan anak belajar daring dengan aman (Waldiyah, 2021).

Orang tua lah kunci utama kesuksesan dalam membentuk karakter anak. Langkah pertama merupakan hal penting yang harus diperhatikan dan dijaga sebaik-baiknya, karena sesungguhnya seorang anak diciptakan dalam keadaan siap untuk menerima kebaikan dan keburukan. Tiada lain hanya kedua orang tualah yang membuat cenderung pada salah satu di antara keduanya. Pembentukan karakter juga sangat ditentukan oleh orang tua, terutama pada masa pertumbuhan. Masa yang menentukan bagaimana pembentukan karakter. Karena itu anak yang sering diberikan nasihat, melihat halhal yang baik, kasih sayang yang cukup, maka setelah dewasa karakter anak akan terbentuk dengan baik. Karakter adalah nilai-nilai perilaku manusia yang berhubungan dengan Tuhan, diri sendiri, sesama manusia, lingkungan, dan kebangsaan yang terwujud dalam pikiran, sikap perasaan, perkataan, dan perbuatan berdasarkan norma-norma agama, hukum tata krama, budaya, dan adat istiadat. Nilai-nilai karakter yang harus ada pada anak yaitu nilai nurani dan nilai memberi. Nilai nurani seperti keberanian, kejujuran, cinta damai. Sedangkan nilai memberi seperti, setia, dapat dipercaya, hormat, sopan, ramah dan baik hati. Oleh karena itu orang tua sebagai pendidik pertama bagi anak sebaiknya juga memiliki kemampuan mengenai nilai-nilai karakter. Pembentukan karakter tidak dapat dilakukan dengan cara menghafal, karena ini melekat di dalam diri manusia. Namun karakter akan terbentuk karena kebiasaan yang dilakukan, sikap yang diambil dalam mengambil keadaan, dan kata-kata yang diucapkan kepada orang lain. Mengingat penting serta kompleksnya masalah yang ada pada anak maka orang tua sebaiknya menanamkan karakter anak yang baik sejak dini, untuk memperkokoh pondasi yang dimiliki anak sehingga di kemudian hari anak tidak terjebak dan terpengaruh akan lingkungan luar rumah. Oleh karena itu, sistem pendidikan yang baik harus menunjukan proses pendidikan dalam keluarga sebagai realisasi tanggung jawab orang tua terhadap pendidikan anaknya.

Penelitian yang berkaitan dengan peran orang tua dalam pendidikan karakter telah dibuat oleh Septi Irmalia dengan judul "Peran orang tua dalam pembentukan karakter anak usia dini" (Irmalia, 2020) dan penelitian yang dilakukan oleh I Wayan Eka Santika dengan judul "Pendidikan Karakter pada pembelajaran daring" (Santika, 2020). Persamaan dalam jurnal penelitian ini, adalah pembentukan karakter pada peserta didik dalam pembelajaran online yang harus dilakukan oleh orang tua, namun perbedaannya dengan penelitian yang dilakukan oleh penulis dengan jurnal yang pertama adalah waktu penelitiannya, yakni peran orang tua dalam pembentukan karakter selama pembelajaran online, sedangkan persamaannya adalah pembentukan karakter yang ditujukan bagi peserta didik, sedangkan perbedaan dengan judul yang kedua adalah peran dari orang tua yang lebih ditekankan cara dan penyampaiannya dari pembelajarannya.

Berdasarkan pemaparan di atas, maka peneliti tertarik untuk meneliti tentang Peran orang tua dalam pembentukan karakter pada peserta didik selama pembelajaran online. Adapun rumusan masalah dalam penelitian ini adalah: 1) 


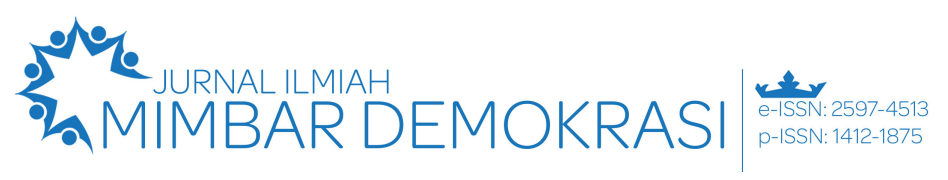

Vol. 21 No. 1 October 2021 | Hal. 19 - 28

Bagaimana peran orang tua dalam pembentukan karakter pada peserta didik dalam pembelajaran online, 2) Bagaimana memberikan pemahaman pentingnya nilai-nilai karakter dalam kehidupan sosialnya di masyarakat, 3) Kendala apa saja yang dihadapi oleh orang tua/wali dalam menumbuhkan nilai-nilai karakter pada peserta didik selama pembelajaran online?

\section{Metode}

Penelitian ini dilaksanakan di Kelurahan Pondok Benda Kecamatan Pamulang Kota Tangerang Selatan pada selama 4 (empat) bulan, yakni dari bulan Januari sampai dengan bulan April 2021. Metode yang digunakan dalam penelitian ini adalah pendekatan kualitatif dengan penelitian studi kasus. Pengumpulan data dilakukan dengan menggunakan wawancara, observasi, dan dokumentasi. Data yang diperoleh kemudian dianalisis dengan kondensasi, penyajian data dan verivikasi data. Pengecekan data menggunakan uji kredibilitas (triangulasi teknik, triangulasi sumber, serta memberchek). Tahapan penelitian yakni, pra penelitian, pra lapangan, kegiatan di lapangan, selanjutnya menganalisis data yang diperoleh).

\section{Hasil dan Pembahasan}

\section{Peran Orang Tua dalam Pendidikan Karakter pada Peserta Didik selama Pembelajaran Online}

Munirwan umar mengungkapkan tentang peran orang tua dalam pendidikan anak di antaranya sebagai pengasuh dan pendidik, pembimbing, motivator, serta fasilitator (Umar, 2015). Mengingat berartinya peranan orang tua dalam mendidik anak, sekian banyak penelitian telah membuktikan jika orang tua mempunyai andil yang sangat besar dalam dalam lingkup pendidikan anak. Pendidikan yang hanya mengandalkan pembelajaran di sekolah belum tentu menjamin keberhasilan anak dalam belajarnya. Sebaliknya, orang tua yang selalu memberi perhatian pada anaknya, terutama perhatian pada kegiatan belajar mereka di rumah, akan membuat anak lebih giat dan lebih bersemangat dalam belajar karena ia tahu bahwa bukan dirinya sendiri saja yang berkeinginan untuk maju, akan tetapi orang tuanya juga memiliki keinginan yang sama. Tujuan dari pendidikan karakter yaitu untuk menyempurnakan akhlak, dapat menjadikan manusia yang berakhlak mulia, manusia yang beradab dan bermartabat dengan melalui olah perasaan, akal dan raganya secara bersamaan. yang sesuai dengan nilai luhur Pancasila sehingga menjadi peradaban nasional yang menjadi contoh bagi bangsa di seluruh dunia. Oleh karena itu tujuan pendidikan karakter harus dapat dilaksanakan dengan penuh kesadaran dan terencana untuk keberlangsungan kemajuan bangsa di masa yang akan datang. Sehingga hasil belajar atau prestasi belajar yang diraih oleh siswa menjadi lebih baik (Nurhasanah, 2020). Sistem pembelajaran daring menjadi pilihan bagi pemerintah Indonesia sebagai alternatif untuk menjaga agar proses belajar-mengajar tetap berlangsung di masa pandemi covid-19. Ada dua dampak yang bisa muncul dari sistem pendidikan yang ditimbulkan oleh pandemi covid-19. Pertama yaitu dampak yang dirasakan oleh banyak keluarga yang tersebar baik di kota maupun di desa dalam kurung waktu singkat. Sebagian besar orang tua di Indonesia belum begitu memahami kegiatan sekolah daring. Bersekolah di rumah menjadi kejutan besar terutama bagi produktivitas kerja bagi orang tua yang terbiasa sibuk dengan berbagai pekerjaan yang sebagian besar aktivitasnya terjadi di luar rumah. Begitu juga dengan masalah psikologis anak, di mana mereka sudah terbiasa belajar di ruang-ruang kelas berhadapan langsung dengan para guru setiap harinya. Semua elemen pendidikan dalam kehidupan sosial terjangkit sakit karena virus covid-19. Pelaksanaan pengajaran akhirnya harus dilakukan dan berlangsung dengan sistem online. Proses ini telah dilakukan pada skala tidak terukur serta teruji, disebabkan keputusan pembelajaran daring muncul di masa yang tak terduga sebelumnya. Tidak dapat dihindari kondisi di desa-desa terpencil di mana berpenduduk usia sekolah sangat padat menjadi serba kebingungan, sebab sarana prasarana informasi teknologi terbatas dan belum memadai.

Di era pandemi covid-19 saat ini tentu peran orang tua akan sangat dibutuhkan sebagai pengganti guru dalam proses belajar. Terlebih dalam menyikapi kebijakan pemerintah untuk menerapkan kegiatan belajar mengajar secara daring (dalam jaringan), demi keamanan siswa termasuk siswa Sekolah Dasar. Salah satu yang digalakkan adalah adanya social distancing. Social distancing merupakan upaya jaga jarak, misalnya seperti menghindari kerumunan, dan kontak fisik. Adanya social distancing tersebut sudah jelas sangat berpengaruh pada dunia pendidikan. Pembelajaran yang dilakukan di sekolah telah diliburkan mulai bulan Maret 2020. Bahkan hingga bulan Mei 2020 saat inipun pembelajaran 
masih dilakukan dari rumah masing-masing. Sesuai dengan Undang-Undang Kekarantinaan Kesehatan Pasal 59 Ayat 3 tahun 2020 menjelaskan bahwa "pembatasan sosial berskala besar ini paling sedikit meliputi peliburan sekolah dan tempat kerja, pembatasan kegiatan keagamaan, dan atau pembatasan kegiatan di tempat atau fasilitas umum." Tantangan tersendiri untuk dunia pendidikan supaya pembelajaran dapat terus berjalan di tengah pandemi covid-19 ini. Salah satu jalan keluar untuk menangani masalah tersebut adalah pembelajaran dilakukan secara daring. Pembelajaran daring ialah pembelajaran yang dilakukan dengan jarak jauh dengan bantuan internet. Dalam pembelajaran daring dibutuhkan sarana dan prasarana, berupa laptop, komputer, smartphone, dan bantuan jaringan internet (Sourial et al., 2018)

Di sisi lain orang tua adalah tempat berlangsungnya pendidikan pertama dalam keluarga, sehingga di usia anak Sekolah Dasar memang dibutuhkan keikutsertaan mereka secara intens dalam proses pedidikan. Salah satu kegiatan belajar yang sangat penting dan memiliki kaitan erat dengan peran orang tua adalah penanaman Pendidikan Karakter. Terlepas dari kegiatan belajar mengajar yang terbatas di era pandemi covid-19 ini, tidak hanya guru di sekolah namun orang tua juga harus memberikan pengajaran kepada anak berupa Pendidikan Karakter sedini mungkin. Pendidikan karakter bisa diartikan sebagai sebuah bantuan sosial agar individu itu dapat bertumbuh dalam menghayati kebebasannya untuk hidup dengan orang lain dengan dunia. Di mana hal tersebut merupakan bentuk kepedulian mereka terhadap kehidupan moral dan sosial anaknya yang akan menjadi tumpuan serta dasar dalam hidup bermasyarakat. Oleh karena itu orang tua harus lebih sabar dalam mengajarkan kepada anak. Supaya tidak dijumpai banyaknya berita kekerasan orang tua dalam mendidik anak dan agar proses kegiatan belajar daring yang dilakukan selama pandemi melalui berbagai aplikasi seperti Whatsapp Group, Google Meet, Google Classroom menjadi lebih maksimal. Untuk itu orang tua dapat mengambil peran salah satunya yang paling penting adalah pemahaman Agama dan diiringi dengan mengajarkan kepada anaknya bagaimana cara untuk berbahasa dan bertutur kata yang baik kepada setiap orang termasuk temannya di sekolah. Anak juga harus diajarkan bagaiamana caranya disiplin dan mandiri terhadap kewajibannya sebagai peserta didik seperti menyiapkan buku dan menyelesaikan tugas di malam hari, membiasakan bangun pagi dan merapikan tempat tidurnnya, dan selalu tertib untuk mengikuti kelas walaupun hanya dilakukan di rumah.

Peran orang tua dalam mendukung pembelajaran anak di rumah menjadi sangat penting, bukan hanya bagi kepentingan lembaga pendidikan namun juga pada orang tua peserta didik tentunya. Meskipun proses pembelajaran daring dilaksanakan hanya melalui jaringan whatsapp yang terbatas, namun antusias orang tua peserta didik sangat besar dalam mendorong anak-anak mereka turut berpartisipasi dalam kegiatan pembelajaran. Para orang tua begitu bersemangat membantu tahap demi tahap di setiap kegiatan pembelajaran daring, dengan membimbing, memotivasi anak anak mereka walaupun sebagian besar orang tua juga disibukan dengan kegiatan lain.

Oleh karena itu, dalam pembentukan karakter juga peran dari keluarga tidak dapat dipisahkan dari kehidupan anak, yang merupakan tempat utama dan pertama dalam memulai kehidupannya. Di dalam keluarga nilai, agama, moral, serta sosial dapat dilakukan lebih efektif ketimbang dilakukan di institusi lainnya. Keluarga berperan penting dalam menanamkan kebiasaan dan pola tingkah laku, serta menanamkan nilai, agama, dan moral sesuai dengan usia dan kultur di keluarganya. Dalam Peraturan Pemerintah Republik Indonesia Nomor 21 Tahun 1994 Tentang Penyelenggaraan Pembangunan Keluarga Sejahtera, 1994 dinyatakan bahwa keluarga memiliki fungsi cinta dan kasih sayang, perlindungan, pendidikan, nilai, agama, moral, serta sosial. Menyatakan bahwa keluarga merupakan tempat utama atau tempat awal dan tempat terdekat anak, karena dalam keluarga tersedia banyak waktu luang untuk dihabiskan bersama dengan anak. juga menyatakan bahwa keluarga menjadi satu bagian yang paling penting dalam menjadikan anak lebih baik salah satunya adalah dengan pendidikan keluarga menjadi salah satu pusat pendidikan untuk anak (Zahrok \& Suarmini, 2018).

Secara tidak langsung anak akan terlatih menjadi pribadi yang memiliki karakter mampu bertanggung jawab terhadap dirinya sendiri. Hal lain yang tidak boleh dilewatkan dalam menanamkan pendidikan karakter kepada anak adalah mengajarkan bagaimana cara bergaul termasuk batasan-batasannya dan cara menyesuaikan diri terhadap lingkungan, khususnya lingkungan baru. Karena pendidikan karakter itu sendiri adalah suatu pengajaran 


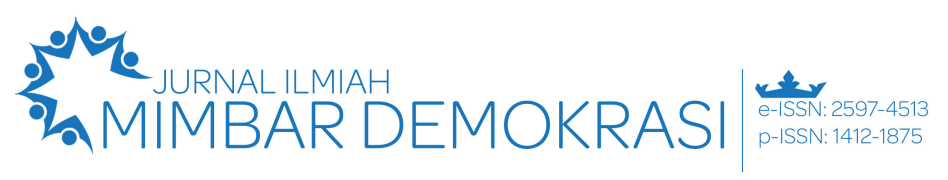

Vol. 21 No. 1 October 2021 | Hal. 19 - 28

berupa kebaikan agar seseorang memiliki pribadi dengan moral dan karkter serta budi pekerti yang baik untuk dirinya sendiri dan bekal dalam hidup bermasyarakat. Karena sudah bukan menjadi rahasia lagi bahwa semakin majunya teknologi saat ini kita juga dapat melihat banyaknya oknum anak muda yang tidak bermoral baik, maka jangan sampai hal negatif tersebut ada pada diri anak kita. Pembelajaran jarak jauh dengan media komunikasi juga menjadikan kurangnya pendampingan dan pemantauan dari guru, sehingga perilaku siswa tidak dapat dikendalikan. Akibat pembelajaran jarak jauh terhadap perilaku siswa menjadi malas, kurang bertanggung jawab dalam menjalankan tugasnya sebagai siswa, kurang disiplin, dan kurang mandiri dalam mengerjakan tugas serta lebih bergantung kepada orang lain, yakni orang tua. Membentuk karakter sulit untuk diterapkan jika pembelajaran dilakukan secara online. Peran orang tua serta strategi yang digunakan sangatlah penting agar pembentukan karakter siswa dapat ditanamkan dengan baik. Hal tersebut tentunya menjadi tugas yang tidak mudah bagi setiap orang tua, karena dalam proses mendidik memerlukan strategi yang baik dimana strategi tersebut harus dimiliki oleh seorang pendidik, terutama dalam penanaman pembentukan karakter terhadap anak pada masa pandemi Covid-19 (Azizah et al., 2020).

Pendidikan karakter dapat ditanamkan dengan melalui pendidikan yang terus berkelanjutan, baik dalam ruang lingkup pendidikan formal (sekolah), non formal (lingkungan sosial), dan informal (lingkungan keluarga) (Setiawan, 2021). Dengan pendidikan karakter yang terintegarasi dalam proses pembelajaran ini menandakan pembelajaran yang bermakna yaitu kapabilitas yang berguna bagi kehidupan peserta baik untuk kepentingan belajar lebih lanjut maupun disumbangkan dalam pemecahan masalah di lingkungan masyarakat. Peran orang tua menjadi sangat penting dalam pembentukan karakter anak untuk siap mengahadapi dunia di masa yang akan datang. Pada awalnya anak akan meniru perilaku orang tuanya, karena orang tua menjadi orang yang paling dekat dan dikaguminya. Setelah itu lingkungan rumah juga berpengaruh dalam pembentukan karakternya. Hal ini dapat dilihat dari cara berpakaian, bersikap, dan perilaku sehari-hari seorang anak yang biasanya mirip dengan orang-orang yang ada dilingkungan rumahnya. Orang terdekat dalam keluarga juga tidak luput dari perhatian anak untuk mengamati dan meniru apa yang dilakukannya, oleh karena itulah menjaga dan membiasakan berperilaku positif memang wajib dilakukan untuk membentuk karakter yang baik pada anak. Pembentukan karakter yang positif ini juga membutuhkan proses yang panjang artinya berlangsung lama. Artinya orang tua juga harus terus menerus untuk mendorong, membimbing, memotivasi dan memfasilitasi demi tercapainya pendidikan yang baik (Irmalia, 2020). Peran tersebut jadi pijakan awal bagi mereka untuk menapaki jenjang-jenjang pendidikan berikutnya.

Sehingga orang tua memiliki peran yang cukup penting dalam mengarahkan, mendidik, maupun membentuk kepribadian anak agar memiliki karakter yang baik, agamis, dan juga humanis. Karakter yang diidamkan tersebut menjadi asa semua orang tua siswa, di mana hal tersebut menjadi penunjang pendidikan formal yang ditempuhnya. Di samping memiliki kemampuan akademis, harapan orang tua tentu menginginkan anaknya memiliki kecakapan, bakat, maupun karakter yang kuat untuk dijadikan bekal dalam mengarungi kehidupan bermasyarkat kelak. Proses pembelajaran ynag dilakukan di rumah menjadi hal yang sangat baik, karena hubungan keluarga lebih terlihat. Selain itu anak menjadi dekat dengan orang tua. Berbagai hal banyak dilakukan pada saat pembelajaran di rumah antara orang tua dan anak. Rasa tanggung jawab akan lebih terlihat, selalu memberikan motivasi juga sangat diperlukan. Karena pada saat pembelajaran di rumah anak mudah bosan, di sini orang tua dituntut sabar dan harus mampu mengondisikan proses pembelajaran. Keluarga berperan penting dalam menanamkan kebiasaan dan pola tingkah laku, serta menanamkan nilai, agama, dan moral sesuai dengan usia dan budaya di keluarganya.

Adapun peran orang tua dalam membentuk karakter siswa selama pembelajaran online dapat dilakukan dengan cara sebagai berikut:

1. Peran orang tua sebagai pendidik di rumah

Selama pembelajaran online, membimbing dan mendidik peserta didik untuk memahami pelajaran di sekolah menjadi tanggung jawab orang tua. Tugas sebagai pendidik tidak hanya dibebankan kepada seseorang yang berprofesi sebagai pendidik saja, akan tetapi adalah semua orang tua, anggota masyarakat dalam lingkungan di mana individu itu berada serta lingkungan kemasyarakatan keagamaan. Peranan orang tua dalam mendidik agar anak dapat hidup dengan baik, bahkan lebih dari itu agar anak dapat tumbuh dewasa. Peran orang tua sebagai 
pendidik utama bagi anak-anaknya dan hal tersebut tidak dapat disanggah. Anak sebagai buah hati yang dilahirkan dan dibesarkan oleh kedua orang tua selayaknya dapat dididik dengan baik karena proses pendidikan merupakan proses dalam menanamkan nilai-nilai yang baik bagi kepribdian anak agar menjadi pribadi yang tangguh, mandiri, beriman dan bertanggung jawab (Muhammad, 2021).

\section{Memberikan motivasi belajar}

Orang tua merupakan motivator bagi anaknya, hal ini dilakukan karena kedekatan antara orang tua dan anak selama pembelajaran online. Motivasi yang diberikan oleh orang tua dalam melaksanakan pembelajaran online diharapkan akan berpengaruh kuat dalam membentuk kepribadian anak. Orang tua dapat memberikan contoh nyata berupa tindakan dan ucapan yang positif dalam memberikan motivasi kepada anak-anaknya. Selain dengan ucapan dan kata-kata, orang tua juga mencukupi fasilitasfasilitas pembelajaran online yang dibutuhkan oleh anak, sehingga anak tidak akan cepat jenuh ketika harus belajar dari rumah.

\section{Keteladanan orang tua}

Pada dasarnya pembentukan karakter seorang peserta didik berawal dari lingkungan keluarga. Oleh karena itu keteladanan orang tua dalam membentuk karakter pada anak harus terus dilakukan agar memberikan dampak positif bagi anak-anaknya selama mereka berada di rumah. Biasanya mereka akan mengingat dan mencontoh kebiasaan yang dilakukan oleh orang-orang terdekatnya, yang berada di lingkungan keluarga. Melalui keluargalah pembentukan karakter dibentuk dan terpelihara, anak-anak otomatis mencontoh dan meneladani perilaku dari para orang tuanya. Jika orang tua memberikan contoh yang baik secara konsisten baik ucapan, perilaku dan tindakan dalam keseharian, maka anak akan mengikuti dan meneladani apa yang dilakukan orang tuanya dengan rasa hormat. Tetapi sebaliknya, jika orang tua memerintahkan anaknya untuk bertindak disiplin dan berbuat baik, sementara ia bertindak sebaliknya, maka anak mungkin menurut jika di hadapan orang tuanya saja, tetapi di luar tersebut tanpa sepengetahuan orang tuanya anak tersebut bertindak sebaliknya (Muhammad, 2021).

Pentingnya Memberikan Pemahaman NilaiNilai Karakter pada Anak dalam Kehidupan Sosial.

Pendidikan karakter adalah pendidikan yang mengajarkan tentang kepribadian, tabiat, sikap maupun akhlak sehingga dapat terbentuk suatu individu seperti apa yang diharapkan. Suatu lembaga pendidikan harus mengedepankan penanaman dan pengembangan nilai-nilai karakter pada peserta didik dalam proses pembelajaran yang kemudian dapat diterapkan dalam kehidupan sehari-hari. Secara umum fungsi pendidikan karakter sesuai dengan fungsi pendidikan nasional, pendidikan karakter ditujukan untuk mengembangkan kemampuan dan membentuk watak serta bangsa yang bermartabat dalam rangka mencerdaskan kehidupan bangsa (Hikmah, 2019). Berkaitan dengan hal tersebut, menurut Zubaedi ada beberapa fungsi diadakannya pendidikan karakter, yaitu:

1. Membentuk dan pengembangan potensi anak Pendidikan karakter berfungsi untuk membentuk dan mengembangkan potensi peserta didik agar peserta didik dapat berpikiran baik, berhati baik dan berperilaku baik sesuai dengan falsafah hidup Pancasila.

2. Perbaikan dan Penguatan

Pendidikan karakter berfungsi untuk memperbaiki karakter peserta didik yang bersifat negatif dan memperkuat peran keluarga, satuan pendidikan, masyarakat dan pemerintah untuk ikut berpartisipasi dan bertanggung jawab dalam pengembangan potensi warga negara menuju bangsa yang maju, mandiri, berkarakter dan sejahtera

3. Penyaring

Pendidikan karakter bangsa berfungsi memilah nilai-nilai budaya bangsa sendiri dan menyaring nilai-nilai budaya bangsa lain yang positif agar menjadi manusia yang berkarakter serta bangsa yang bermartabat (Zubaida, 2020).

Selain itu, dengan membentuk karakter pada anak juga akan memberikan manfaat sebagai berikut:

1. Mengembangkan potensi kalbu /nurani/ afektif peserta didik sebagai manusia dan warga negara yang memiliki nilai-nilai budaya dan karakter bangsa.

2. Mengembangkan kebiasaan dan perilaku peserta didik yang terpuji dan sejalan dengan nilai-nilai universal dan tradisi budaya bangsa yang religius

3. Menanamkan rasa tanggung jawab serta jiwa kepemimpinan peserta didik sebagai generasi penerus bangsa

4. Mengembangkan lingkungan kehidupan sekolah sebagai lingkungan belajar yang aman, jujur, bersahabat, penuh 


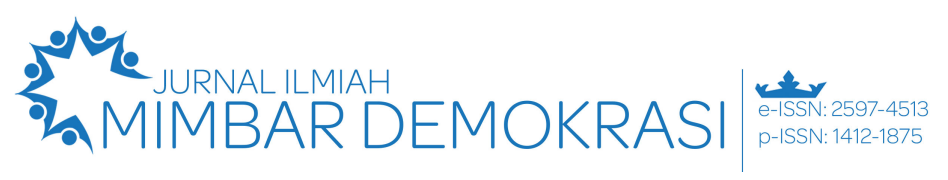

Vol. 21 No. 1 October 2021 | Hal. 19 - 28

kreativitas dan dengan rasa kebangsaan yang tinggi serta penuh kekuatan ( $\mathrm{La}$ Hadisi, 2015).

Pendidikan karakter juga turut serta dalam membangun integritas, disiplin diri, ekspresi cinta, dan kasih sayang (Jeynes 2019). Dengan demikian, pendidikan karakter bisa diartikan sebagai bentuk penanaman nilai-nilai (value) atau karakter yang baik kepada siswa dalam rangka mengarahkan tumbuh kembang anak agar memiliki sifat yang baik. Karakter juga dapat dipahami sebagai cara berpikir serta perilaku yang menjadi ciri khas setiap individu untuk hidup dan bekerja sama di lingkungan keluarga, masyarakat, dan bangsa. Dalam diskursus psikologi, karakter adalah perangai atau watak dan sifat dasar yang khas yang dimiliki setiap individu. Jadi, karakter dapat dipahami sebagai manifestasi sifat seseorang. Lebih lanjut Thomas Lickona (2009) merumuskan delapan nilai pendidikan karakter: belajar sepanjang hayat dan berpikir kritis; rajin dan cakap; cakap secara sosial maupun emosional; pemikir etis; respek dan berkomitmen terhadap tanggung jawab moral; disiplin dan menjaga gaya hidup sehat; berkontribusi terhadap lingkungan masyarakat, serta menjadi warga negara yang demokratis; dan memiliki spiritualitas tinggi guna menggapai kemuliaan hidup.

Dijelaskan lebih lanjut ada empat alasan mendasar mengapa sistem pendidikan di Indonesia perlu menekankan pada pendidikan karakter, alasan tersebut yaitu:

1. Karena banyak keluarga (tradisional maupun non-tradisional) yang tidak melaksanakan pendidikan karakter;

2. Karena peran sekolah tidak hanya bertujuan membentuk anak yang cerdas, tetapi juga anak yang baik;

3. Kecerdasan seorang anak hanya bermakna manakala dilandasi dengan kebaikan;

4. Karena membentuk peserta didik agar berkarakter tangguh bukan hanya sekadar tugas tambahan bagi guru, melainkan tanggung jawab yang melekat pada perannya sebagai guru.

Dengan pendidikan karakter yang terintegarasi dalam proses pembelajaran ini menandakan pembelajaran yang bermakna yaitu kapabilitas yang berguna bagi kehidupan peserta baik untuk kepentingan belajar lebih lanjut maupun disumbangkan dalam pemecahan masalah di lingkungan masyarakat (Santika, 2020).
Tujuan pendidikan karakter secara umum adalah untuk membangun dan mengembangkan karakter peserta didik pada setiap jalur, jenis, dan jenjang pendidikan agar dapat menghayati dan mengamalkan nilai-nilai luhur menurut ajaran agama dan nilai-nilai luhur dari setiap butir sila Pancasila. Selain itu juga untuk meningkatkan mutu penyelenggaraan dan hasil pendidikan yang mengarah pada pencapaian pendidikan karakter dan akhlak mulia peserta didik secara utuh, terpadu, dan seimbang (Tetik, 2016). Pendidikan karakter bertujuan untuk meningkatkan mutu penyelenggaraan dan hasil pendidikan di sekolah yang mengarah pada pencapaian pembentukan karakter dan akhlak mulia peserta didik secara utuh, terpadu, seimbang, dan sesuai dengan standar kompetensi lulusan. Melalui pendidikan karakter diharapkan peserta didik mampu secara mandiri meningkatkan dan menggunakan pengetahuannya dalam mempersonalisasi nilainilai karakter dan akhlak mulia sehingga terwujud dalam perilaku sehari-hari.

Memberikan pemahaman pentingnya karakter kepada peserta didik mutlak dilakukan oleh orang tua selama pembelajaran online ini, karena dengan memberikan pendidikan karakter maka akan tercipta:

1. Peserta didik akan terbiasa berperilaku baik kepada siapapun, kapanpun, dan di manapun

2. Peserta didik akan memiliki moral dan rasa sosial yang tinggi di mana saja berada

3. Peserta didik akan memiliki sikap disiplin dalam berbagai tugas-tugas yang diberikan

4. Peserta didik akan memiliki toleransi dan tenggang rasa yang tinggi

5. Peserta didik akan kreatif dan mandiri dalam mengerjakan tugas maupun kegiatan-kegiatan yang berhubungan dengan pendidikannya, maupun kegiatan di luar sekolah

6. Peserta didik akan berani menentukan sikap sehingga tidak mudah terpengaruh oleh hal-hal negatif yang didapatkannya dalam pergaulan di kemudian hari

7. Membekali anak dengan nilai nilai sosial. kemanusiaan dan kebaikan

8. Peserta didik akan lebih demokratis dalam kegiatan berorganisasi, baik itu di lingkungan sekolah maupun dalam kegiatan sosialnya 
9. Membentuk rasa percaya diri yang tinggi pada anak, sehingga mereka bisa mengembangkan potensi yang dimilikinya menjadi individu yang berperilaku baik dan positif

10. Mampu mengendalikan diri dalam situasi dan keadaan ketika bergaul di luar rumah sehingga mereka bisa mengimplementasikan terhadap apa yang diketahui dan dicintai yang terkait dengan kebaikan-kebaikan. Tentunya yang diharapkan di sini adalah bagaiamana diri sendiri atau peserta didik memberikan manfaat yang sebesarbesarnya kepada orang dalam pergaulan sosial.

11. Peserta didik akan memiliki sifat ingin tahu terhadap hal-hal baru yang belum diketahuinya

12. Peserta didik akan memiliki rasa cinta tanah air dan semangat kebangsaan yang tinggi, peduli pada lingkungan sekitar, serta cinta damai.

Menurut Thomas Lickona, setidaknya ada tujuh alasan mengapa character education harus diberikan kepada warga negara sejak dini, yaitu;

1. Ini merupakan cara paling baik untuk memastikan para murid memiliki kepribadian dan karakter yang baik dalam hidupnya.

2. Pendidikan ini dapat membantu meningkatkan prestasi akademik anak didik.

3. Sebagian anak tidak bisa membentuk karakter yang kuat untuk dirinya di tempat lain.

4. Dapat membentuk individu yang menghargai dan menghormati orang lain dan dapat hidup di dalam masyarakat yang majemuk.

5. Sebagai upaya mengatasi akar masalah moral-sosial, seperti ketidakjujuran, ketidaksopanan, kekerasan, etos kerja rendah, dan lain-lain.

6. Merupakan cara terbaik untuk membentuk perilaku individu sebelum masuk ke dunia kerja/ usaha.

7. Sebagai cara untuk mengajarkan nilai-nilai budaya yang merupakan bagian dari kerja suatu peradaban (Khotim Shobariah, 2019).

Oleh karena itu sentuhan pendidikan bagi anak tidak sebatas hanya guru di sekolah saja, orang tua di rumah harus menguatkan pendidikan yang diterima anak di sekolah, sehingga keterpenuhan pendidikan bagi anak tercukupi dan memberikan dampak yang baik bagi anak pada masa dewasa nanti orang tua merupakan guru terbaik bagi anak-anaknya dikarenakan kedekatan yang terjalin secara panjang, di balik itu keterikatan jalinan orang tua dan anak yang saling memahami dan dalam menemukan kemampuan anak sebenarnya orang tua mampu melakukan hal tersebut dengan tindakan discovering ability yaitu menjelajah kemampuan anak sehingga anak terbangun konsep diri positif dalam kepribadian anak. Peran orang tua sangat dibutuhkan besar sebagai upaya dalam mengembangkan sikap afektif, kognitif, dan psikomotorik anaknya dikarenakan dengan memberikan pendidikan yang berkualitas sehingga dapat mensinergikan peran sekolah, guru, dan orang tua menjadi suatu kestabilan dalam memenuhi nilai-nilai karakter sebagai pengembangan etika dan moral sehingga mereka akan mengimplementasiannya dalam kehidupan pergaulan di masyarakat.

\section{Kendala Orang Tua dalam Menumbuhkan Nilai-Nilai Karakter selama Pembelajaran Online}

Beralihnya pembelajaran ke rumah setidaknya menuntut pelaksanaan pembelajaran dilakukan secara daring menggunakan media teknologi, seperti laptop atau telepon pintar. Tentunya semua ini menjadi tantangan baru bagi berbagai pihak, baik guru, orang tua, ataupun peserta didik. Mulai dari penyampaian materi hingga pemberian tugas hampir semuanya dilakukan melalui teknologi informasi. Dalam hal ini, jelas sekali dampak positif teknologi untuk memudahkan pekerjaan manusia. Tetapi di sisi lain akibat penggunaan teknologi ini berbagai permasalahan muncul, khususnya di masa belajar dari rumah ini. Alih-alih menggunakan telepon pintarnya untuk belajar, banyak sekali anak-anak justru menyalahgunakannya. Berbagai macam kendala yang dihadapi orang tua pada proses pembelajaran yang dilakukan di rumah orang tua yang hanya salah satu saja yang bekerja juga merasa terbebani dengan pembelajaran online ini. Banyaknya tugas-tugas yang diberikan oleh guru juga menjadi beban bagi peserta didik, sehingga mereka menjadi jenuh, sebab setiap hari selalu berkutat dengan tugas-tugas yang diberikan, hal ini juga akan berdampak pada orang tua yang tingkat pendidikannya rendah, dan tentunya materi pembelajaran yang dialami dahulu dengan 


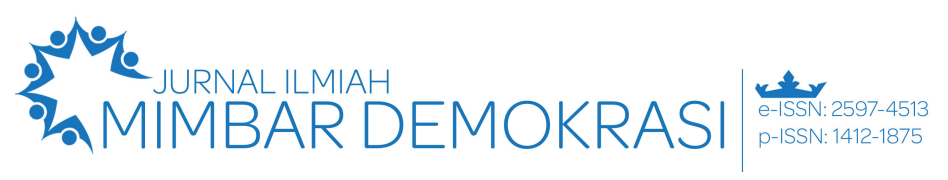

Vol. 21 No. 1 October 2021 | Hal. 19 - 28

sekarang berbeda, tidak banyak orang tua pahami. Hasilnya apa yang diajarkan oleh anaknya sesuai dengan kemampuan orang tuanya. Selain hal itu orang tua yang tidak hanya membimbing anaknya, juga harus memperhatikan psikis anak. Hal ini tentu menjadi suatu yang harus lebih diperhatikan. Nilai yang baik namun setiap harinya anak stres, hal ini akan tidak baik. Namun hendaknya seimbang. Secara umum kendala yang mendasar yaitu orang tua tidak bisa mendampingi secara penuh dan menjawab pertanyanpertanyaan atau membantu memecahkan akan materi yang kurang dipahami oleh anak.

Selain itu, ibu rumah tangga juga terkadang mengalami kesulitan membagi waktu mengontrol penggunaan handphone anaknya dengan kesibukan sehari-hari sebagai ibu rumah tangga. Selain itu banyaknya ibu rumah tangga yang cukup mengalami kesulitan mendampingi anak mengerjakan soal-soal latihan yang diberikan guru dari sekolah. Kendati hanya materi sekolah dasar, menurutnya jauh lebih kompleks ketimbang waktu ia sekolah dulu, penggunaan kouta yang lebih boros juga menjadikan kendala bagi sebagian orang tua, sebab pengeluaran menjadi bertambah, sedangkan pendapatan tidak bertambah, bahkan ada yang menurun karena terdampak pandemi covid-19. Selain hal yang disebutkan tadi, kekhawatiran orang tua semakin meningkat mengingat anak anak ini sering menggunakan gawai di luar pengawasan orang tua, dan menyalahgunakan gawai ini untuk membuka situs-situs yang belum diperbolehkan dibuka oleh mereka.

\section{Simpulan}

Peran orang tua dalam pembentukan karakter peserta didik sangat dibutuhkan sekali mengingat pada masa pandemi ini mereka hampir 24 jam bersama keluarga, sehingga pendidikan mereka sangat bergantung pada orangtuanya sebagai tempat bertanya, berguru, berdiskusi, mengawasi, menjaga, dan membimbing kegiatan mereka sehari-hari di rumah. Terbatasnya komunikasi peserta didik dengan guru menjadikan orang tua harus berperan ganda dalam membimbing anak anaknya di rumah. Namun di balik itu semua, orang tua dapat memberikan perhatian, pemahaman dan waktu yang lebih banyak kepada anak anaknya mengenai pembentukan nilai-nilai karakter kepada mereka, seperti memberikan contoh keteladanan dan sikap mereka yang berkaitan dengan materi dan mempraktekannya langsung dalam kehidupan bermasyarakat di sekelilingnya agar mereka tidak terlalu jenuh berada terus belajar di dalam rumah, walaupun ada beberapa kendala yang terjadi dalam membimbing peserta didik ini di rumah, namun hal ini bisa diminimalisir, mengingat tanggung jawab orang tua dalam membimbing anak anaknya belajar di rumah, jadi hal-hal yang bisa dilakukan oleh orang tua di antaranya: selalu memberikan motivasi kepada anak-anaknya agar tetap menjalani kegiatan belajar dari rumah karena keadaan yang belum memungkinkan untuk belajar di sekolah, sering berkomunikasi dengan guru mata pelajaran untuk menanyakan keaktifan anaknya mengikuti pembelajaran, konsultasi dengan guru jika orang tua tidak paham cara mengajar dan memberikan contoh berkaitan dengan materi, menambah referensi lain yang berkaitan dengan materi pembelajaran, tidak malu juga untuk bertanya kepada sesama orang tua peserta didik, kepada tetangga, atau kepada saudara yang memiliki tingkat pendidikan yang lebih tinggi, juga belajar untuk menambah kemampuan kita untuk bisa mengakses materi pembelajaran melalui media internet.

\section{Referensi}

Azizah, L. S. N., Ispiyana, N., \& Nuryah, S. (2020). Strategi Orang Tua Dalam Menanamkan Pendidikan Karakter Anak Pada Masa Pandemi Covid-19. Academica: Journal Of Multidisciplinary Studies, 4(2), 245-256.

Hikmah, N. (2019). Pentingnya Pendidikan Karakter Sejak Usia Dini. Kompasiana.

https://www.kompasiana.com/nurulnikm ah12/5dcac869097f3647a71e1252/penting nya-pendidikan-karakter-pada-anak-usiadini?page $=$ all

Irmalia, S. (2020). Peran Orang Tua Dalam Pembentukan Karakter Anak Usia Dini. El-Hamra, 5(1), 31-37. http:// journal.elhamra.id/index.php/el/index

Jeynes, W. H. (2019). A meta-analysis on the relationship between character education and student achievement and behavioral outcomes. Education and Urban Society, 51(1), 33-71.

Khotim Shobariah. (2019). Pendidikan Karakter: Pengertian, Fungsi, Tujuan, dan Urgensinya. Https://Smkwidyanusantara.Sch.Id/Read /5/Pendidikan-Karakter-PengertianFungsi-Tujuan-Dan-Urgensinya. https://smkwidyanusantara.sch.id/read/5 
/ pendidikan-karakter-pengertian-fungsitujuan-dan-urgensinya, diakses tanggal 8 September 2021

La Hadisi. (2015). Pendidikan Karakter Pada Anak Usia Dini La Hadisi. Jumal Al-Ta'did, 8(2), 50-69.

http:/ / repository.iiq.ac.id/handle/123456 $789 / 228$

Lickona, T. (2009). Educating for character: How our schools can teach respect and responsibility. Bantam.

Muhammad, G. (2021). Peran Orang Tua Dalam Mengimplementasikan Pendidikan Karakter Pada Masa pembelajaran Jarak Jauh. 2(1), 1429.

https://doi.org/https://doi.org/10.47281 / fas.v2i1.31

Nurhasanah. (2020). Peran Orang Tua dalam Pembelajaran Daring di Masa Pandemi Covid 19 pada Kelompok B.5 TK Kemala Bhayangkari Bone. Educhild, 2(2), 58-67. http://dx.doi.org/10.31219/osf.io/nsv42

Santika, I. W. E. (2020). Pendidikan Karakter pada Pembelajaran Daring. Indonesian $V$ alues and Character Education Journal, 3(1), 8-19.

Setiawan, A. (2021). Pendidikan Karakter pada Peserta Didik di Masa Pandemi Covid-19 Berbasis Keluarga. Jurnal Ilmiah Mandala Education, 7(1), 319-327. http:/ / ejournal.mandalanursa.org/index.p $\mathrm{hp} / J I M E /$ indexterakreditasiPeringkat4

Sourial, N., Longo, C., Vedel, I., \& Schuster, T. (2018). Daring to draw causal claims from non-randomized studies of primary care interventions. Family Practice, 35(5), 639643.

https://doi.org/10.1093/fampra/cmy005

Tetik, A. K. (2016). Peran Orang Tua Dalam Pendidikan Karakter Di Kelas II Sdn Beringin 02 Semarang. https://lib.unnes.ac.id/28345/

Umar, M. (2015). Peranan orang tua dalam peningkatan prestasi belajar anak. JURNAL EDUKASI: Jurnal Bimbingan Konseling, 1(1), 20-28.

Waldiyah, S. (2021). Peran Orang Tua dalam Pembelajaran di Masa Pandemi. Radarsemarang.Jawapost.Com. https:/ / radarsemarang.jawapos.com/rubri k/untukmu-guruku/2021/04/10/peran- orang-tua-dalam-pembelajaran-di-masapandemi/

Zahrok, S., \& Suarmini, N. W. (2018). Peran Perempuan Dalam Keluarga. IPTEK Journal of Proceedings Series, O(5), 61. https://doi.org/10.12962/j23546026.y201 $8 i 5.4422$

Zubaida. (2020). Implementasi Pendidikan Karakter Anak Usia Dini Pada OrangTua yang Bekerja. Jurnal Golden Age, 4(02), 124 142.

https://doi.org/10.29408/jga.v4i02.2427 